\title{
Assessment of Superimposed Signal and Power Transmission System in Implanted TES
}

\author{
S. Matsumura, K. Kato, Y. Kohata*, T. Sakamaki, T. Takura*, F. Sato*, H. Matsuki, \\ K. Seki**, Y. Handa**, and T. Sato \\ Graduate School of Biomedical Engineering, Tohoku Univ., 6-6-04 Aoba, Aramaki, Aoba-ku, Sendai, Miyagi 980-8579, Japan \\ *Graduate School of Engineering, Tohoku Univ., 6-6-05 Aoba, Aramaki, Aoba-ku, Sendai, Miyagi 980-8579, Japan \\ ${ }^{* *}$ Graduate School of Medicine, Tohoku Univ., 2-1 Seiryocyo, Aoba-ku, Sendai, Miyagi 980-8575, Japan
}

\begin{abstract}
Therapeutic electrical stimulation (TES) is electrical stimulation to treat disorders caused by abnormalities in nerves. We have been researching implanted TES that stimulates objective nerves directly inside the body. Prior to this, separate coils were used in implanted TES to transmit power and signals. However, the two-coil system presents several problems. For example, it is necessary to carefully design both coils because the one for power transmission is more powerful than the one for signal transmission, and the power magnetic field interferes with the signal magnetic field. That makes it extremely difficult to design these coils flexibly. To solve this problem, we have begun research on establishing a different method that would increase the flexibility with which coils could be designed. The concept underlying this new approach was to transmit power and signals simultaneously with the same magnetic field. To achieve this, we superimposed the signal on the power. In the first step in this research, we ascertained that this superimposed system of transmission could drive the system for implanted TES.
\end{abstract}

Key words: superimposed transmission, phase shift keying, modulation, Therapeutic Electrical Stimulation (TES)

\section{完全埋込型 TES 用電力信号重畳伝送システムに関する基礎検討 \\ 松村聖司・加藤健太郎・木幡陽介* ・ 酒巻貴子・田倉哲也* ・佐藤文博* ・ 松木英敏 ・ \\ 関和則 $* * \cdot$ 半田康延 $* * \cdot$ 佐藤忠邦 \\ 東北大学大学院医工学研究科, 宮城県仙台市青葉区荒巻字青葉 6-6-04 (下 980-8579) \\ *東北大学大学院工学研究科, 宮城県仙台市青葉区荒巻字青葉 6-6-05 ( $=980-8579)$ \\ **東北大学大学院医学系研究科, 宮城県仙台市青葉区星陵町 2-1 ( $9980-8575)$}

\section{1.はじめに}

疾患を有する神経系に刺激を加えることで, 神経系を正 常な状態に戻すことを目的とする治療法を神経刺激療法と 呼ぶ。この神経刺激療法の一つに, 治療対象の神経系に電 気刺激を加える治療法があり治療的電気刺激 (Therapeutic Electrical Stimulation, TES）と呼ばれている1)。TESの 一部は表面電極を用いた刺激治療機器として実用化されて いる. この機器を用いた治療法は, 仙骨部表面治療的電気 刺激 (Sacral Surface Therapeutic Electrical Stimulation, SS-TES）と呼ばれ，仙骨部奥にある骨盤内蔵神経を，皮膚 表面から電気刺激することで，その神経が支配する内臓機 能の正常化を図る ${ }^{2)}$ 。この表面電極刺激は機器が簡便で済 む反面，目的の神経のみを刺激することが困難であり，刺 激時に痛みを伴う等の問題がある。そこで我々は, 体内に 埋込可能な超小型電気刺激素子で治療対象の神経を直接刺 激できる，完全埋込型TESの開発について検討を行ってい る. 完全埋込型TESにおいて, 体内に留置される小型刺激 素子は, 体外と接触する部分を一切持っていない. 従って, この刺激素子への刺激電力の供給及び，刺激制御用信号の 伝送には，小型素子に設置された小型コイルと，体外に設 置されたコイル間での電磁誘導による非接触伝送が採用さ れている. 現在, 埋込素子は, 電力受電用コイルと信号受 信用コイル，及び得られた電力と信号をもとに刺激波形を 生成するための回路から構成されている。また，体外から 埋込素子への給電および信号伝送には，給電用コイル，信 号伝送用コイルと異なる二個のコイルが用いられている. しかし，給電と信号伝送に異なるコイルを用いることで, 給電用コイルと信号伝送用コイルの間に干渉が生じるため, コイル設計の自由度が制限されてしまう。この制限を無く
し，コイル設計の自由度を増すことを目的として，単一の コイルで電力と信号を同時に伝送する方式の検討を行った.

\section{2. 完全埋込型 TES 用電力信号重畳伝送システム}

\section{1 伝送方式}

電力と信号を単一のコイルを用いて同時に伝送する為，我々は， 信号を電力に重畳して伝送する方式を検討した. Fig. 1 に重畳伝 送方式の概略図を示す。まず，体外側ユニットで $100 \mathrm{kHz}$ の方形 波を作成し, この方形波に刺激制御用信号を位相偏移変調 (Binary Phase Shift Keying, BPSK）する. 変調波はフルブリッジインバ 一タを経由することで, 増幅され, 体外側コイルに送られる. 体 外側コイルに送られた変調波は, 電磁誘導によって, 体内側ユニ ットのコイルに非接触で伝送される. そして, 体内側コイルで受

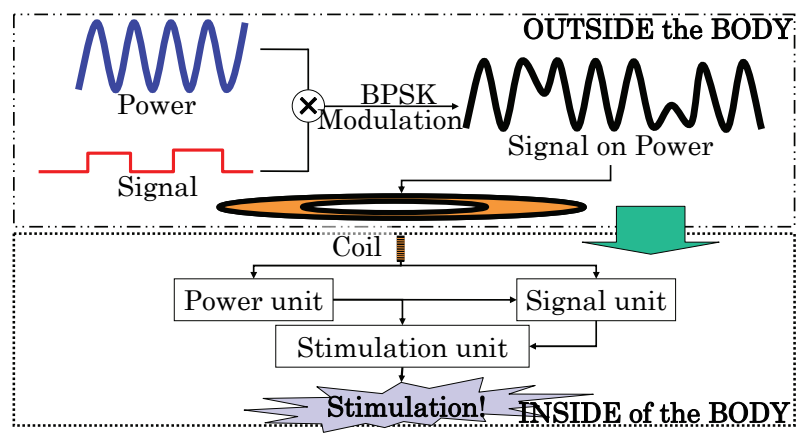

Fig. 1 Superimposed signal and power transmission system in implanted TES. 


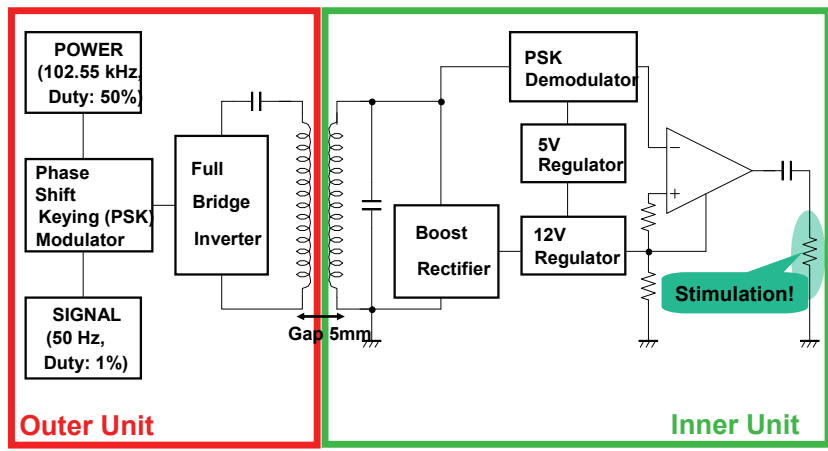

Fig. 2 Circuit block diagram of superimposed signal and power transmission system for implanted TES.

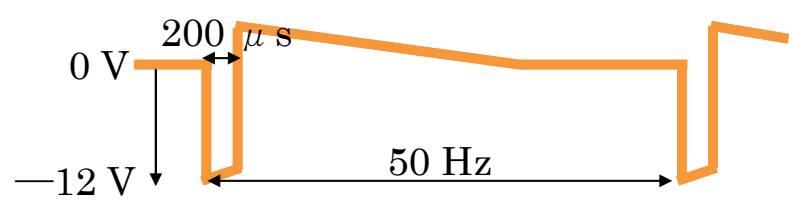

Fig. 3 Stimulation wave.

信された変調波は，整流回路とBPSK 復調回路にそれぞれ伝送さ れる. 整流回路では，変調波を整流し，BPSK 復調回路を含む体 内側回路に電力を供給する.一方, BPSK 復調回路では, 変調波 を復調し，信号を取り出す．最後に，刺激波形を生成する為の回 路に，整流回路から得られた電力が供給され，BPSK 復調回路で 復調された信号が入力されることで, 刺激波形が生成される.以 上が完全埋込型TESにおける電力信号重畳伝送システムの概要で ある.

\section{2 位相偏移変調}

本検討では, 変調方式として BPSK 変調を採用している. BPSK 変調を採用した主な理由は二つある。一つは, 本方式では体内側 で必要とする電力を，信号の搬送波を整流することで得ている. 従って, 常に安定した電力を得る為には, 搬送波の振幅が常に一 定であることが求められる. BPSK 変調波の式は,

$$
S_{B P S K}=A \cos \left(2 \pi f_{c} t+\phi_{i}\right) \quad\left[\phi_{i}=0, \pi\right],
$$

$S_{B P S K}$ : BPSK 変調波, $f_{c}$ : 搬送波周波数, $A$ : 搬送波振 幅, $\phi_{i}$ : 変調位相と表される. (1)式より BPSK 変調では, 搬送波振幅が一定であることが確認できる.

電磁誘導で変調波を伝送する際, 変調波を増幅する為にコイル とコンデンサによる共振をとる必要がある. この共振をとる為に は，搬送波周波数が一定であることが望ましい，コイル形状が決 まっていて，コイルのインダクタンスが定まっている場合，共振 条件を満たす為のコンデンサの值は, 以下の式で表される.

$$
C=1 /\left(2 \pi f_{c}\right)^{2} L \text {. }
$$

従って共振をとる場合, 搬送波の周波数が変化すると, コンデン サの值が一意に定まらず好ましくない.この点, BPSK変調では, (1)式より搬送波周波数は一定である.

以上，これら二つの条件を満たす変調方式として，BPSK 変調 方式を採用した。

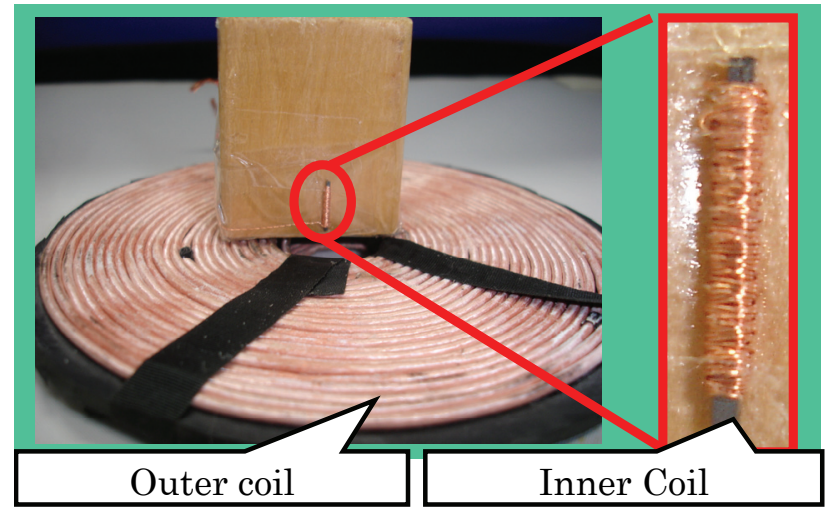

Fig. 4 Coils for transmission.

Table 1 Specification of coils (at $102.55 \mathrm{kHz}$ ).

\begin{tabular}{|c||c|c|}
\hline & Outer coil & Inner coil \\
\hline \hline Figure & dual spiral & solenoidal \\
\hline Material & litz wire ( copper) & litz wire ( copper) \\
\hline $\begin{array}{c}\text { Ferrite } \\
\text { core }\end{array}$ & none & $\begin{array}{c}\mathrm{N}-120 \mathrm{~L} \\
(0.7 \mathrm{~mm} \times 0.7 \mathrm{~mm} \times 10 \mathrm{~mm})\end{array}$ \\
\hline Size & $\begin{array}{c}\text { OD: } 105 \mathrm{~mm}, \\
\text { ID: } 35 \mathrm{~mm}\end{array}$ & $1 \mathrm{~mm} \times 1 \mathrm{~mm} \times 10 \mathrm{~mm}$ \\
\hline Turns & 25 (at each layer) & 150 \\
\hline Inductance & $124.6 \mu \mathrm{H}$ & $111.6 \mu \mathrm{H}$ \\
\hline $\begin{array}{c}\text { Q-value } \\
\text { Resonance } \\
\text { capacitor }\end{array}$ & $\begin{array}{c}133 \\
\text { film capacitor } \\
(19 \mathrm{nF})\end{array}$ & $\begin{array}{c}41 \\
(22 \mathrm{nF})\end{array}$ \\
\hline
\end{tabular}

\section{3. 重畳伝送実験}

\section{1 実験方法}

本検討では, 完全埋込型TES での使用を想定した構成で, 電力 信号重畳伝送実験を行った. 本実験の目的は, 完全埋込型TES シ ステムにおいて電力信号重畳伝送の可否を確認することである. 本実験で作成した体外側及び体内側回路のブロック図を Fig. 2 に示寸.

体外側回路では, 周波数 $102.55 \mathrm{kHz}$, Duty 比 $50 \%$ の方形波を 搬送波として, 周波数 $50 \mathrm{~Hz}$, Duty 比 $1 \%$ 方形波を刺激波形生 成の為の信号として, それぞれ作成した. そして, 信号を搬送波 にBPSK 変調した後, 変調波は, フルブリッジインバータで増幅 され，体外側コイルから体内側コイルへ非接触に伝送される.

体内側回路では, 受信した変調波の周波数で共振をとって増幅 した後, 電力用整流回路と BPSK 復調回路に伝送される. 電力用 整流回路では, 変調波を三倍昇圧整流した後, $12 \mathrm{~V}$ と $5 \mathrm{~V}$ の電圧 を生成する. 生成された $12 \mathrm{~V}$ の電土は, 刺激波形生成回路に電 力を供給し， $5 \mathrm{~V}$ の電王は BPSK 復調回路に電力を供給する. 一 方, BPSK 復調回路では, 得られた電力を利用して, 変調波から 刺激制御用信号を復調し, 刺激波形生成回路に制御信号を伝送寸 る. 最後に, 刺激波形生成回路では, 供給された電力と復調され 


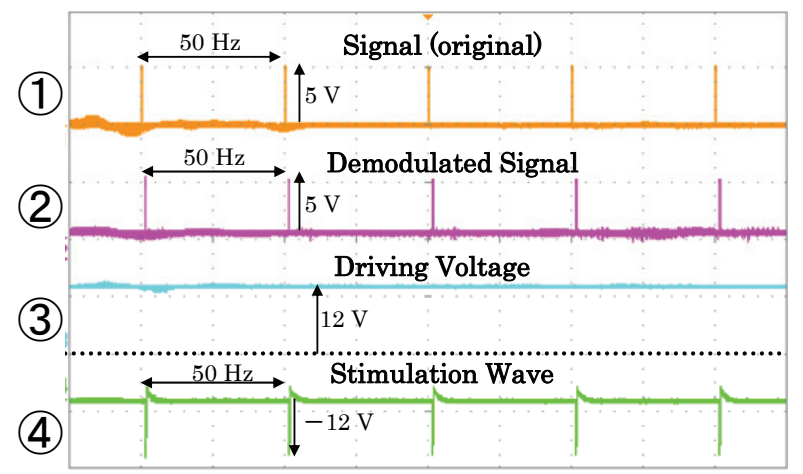

Fig. 5 Results (original signal, demodulation signal, fed power and generated stimulation wave, $10 \mathrm{~ms} / \mathrm{DIV})$.

た制御信号を用いて所望の刺激波形を生成する.

次に，本実験で最終的な目標とする刺激波形を紹介寸る．目標 の刺激波形は，骨盤内臟神経を刺激対象とした場合の刺激波形を 採用した. その波形概要を Fig. 3 に示寸. 波形は, 振幅 $-12 \mathrm{~V}$, 周波数 $50 \mathrm{~Hz}$ ，刺激幅 $200 \mu \mathrm{s}$ の負極性パルス波形である.

最後に, 本実験で伝送に使用したコイルの形状を Fig. 4 に，コ イルのスペックを Table 1 に紹介する. また今回の実験では重畳 伝送の可否を確認することを目的としているので，非接触伝送距 離であるコイル間ギャップは, 近距離 $5 \mathrm{~mm}$ に設定した.

\section{2 実験結果}

Fig. 5 に伝送実験の結果を示した. Fig. 5 の時間軸スケールは $10 \mathrm{~ms} / \mathrm{DIV}$ であり，(1)の波形は, 体外側回路で生成された Duty 比 $1 \%$, 周波数 $50 \mathrm{~Hz}$ の刺激制御用信号, (2)の波形が体内側て復 調されたDuty 比 $1 \%$, 周波数 $50 \mathrm{~Hz}$ の復調信号, (3)波形が体 外側から体内側一伝送された変調波を電力用ユニットて整流した 後の波形, そして(4)の波形が体内側で供給された電力と復調信号 を用いて生成された，本実験で目標としていた刺激波形である.

また, Fig. 5 の時間軸を $100 \mu \mathrm{s} / \mathrm{DIV}$ に拡大した波形を，Fig. 6 に示寸。

まず，重畳伝送によって伝送された刺激制御用信号が，正しく 復調されているのかについて検討を行った. Fig. 5 及び Fig. 6 で の(1)と(2)の波形を比較したところ，両波形共にDuty 比 $1 \%$ ，周 波数 $50 \mathrm{~Hz}$ が確認でき，両波形がほぼ一致していることから，信 号の復調は正しく行われていることが確認された。

次に, 体内側で要求された電力が供給されているかについての 検討は, Fig. 5 (3)から安定して $12 \mathrm{~V}$ の電圧がとれていることが 確覠できた為, 電力は安定的に供給されていることが確認できた.

さらに，体外側から体内側に伝送された電力と刺激制御用信号 から, 所望の振幅が $-12 \mathrm{~V}$, 周波数が $50 \mathrm{~Hz}$, 刺激幅が $200 \mu \mathrm{s}$ で ある負極パルス波形が生成されたことが，Fig. 5 及び Fig. 6 の(4) から確認できた。

最後に，マルチメーターを用いて整流後の体内側回路の消費電 力を測定したところ，約 $200 \mathrm{~mW}$ であることが確㪊できた.

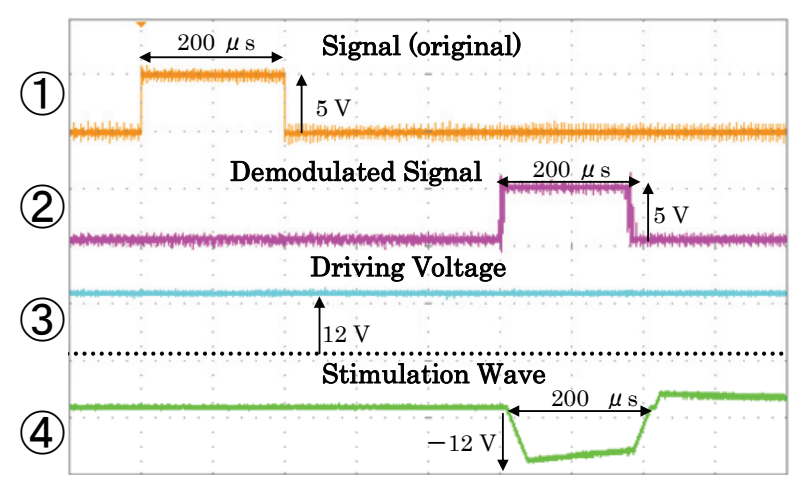

Fig. 6 Results (expanded time scale, $100 \mu$ s/DIV).

以上の実験結果より, 完全埋込型 TES において電力信号重畳伝 送システムが有望であることを確かめることができた.

4. まとめ

本報告では, 完全埋込型TES に対して, 電力に刺激制御用信号 を重畳させた伝送システムの有望性に関する検討と行った. その 結果, 電力伝送用と刺激制御用信号伝送用にそれぞれ異なるコイ ルを用いていた従来の伝送システムに対し，コイル設計の簡単化 を目的として単一のコイルで電力と信号を共に伝送する電力信号 重畳伝送システムは有望であることが確認できた.

しかし, 幾つかの課題も浮き彫りとなった. 数十 kbps オーダー 以上の高速な通信には現時点では, 対応できないといった点が挙 げられる.今回は刺激波形が単純であった為に, 所望の波形を生 成することができたが，将来的に多くの情報量を必要と寸る刺激 波形が求められてきた場合には, 変調方式から見直寸必要性があ ると考えられる. また, 現状, 通信の方向が体外側から体内側一 の一方向通信しかできないが, 安定的な通信状況を確立する為に も，これを双方向通信が可能となるように改善していく必要があ ると考えられる. さらに生体中で使用した場合において，伝送シ ステムが温度変化や外部杂隹音からの影響に対してどの程度安定し ているかを評価する為にも，動物実験等を通して生体中における 伝送システムの評価を行うことが必要である.

以上のように, 課題点もあるが, 骨盤内臟神経を対象とした完 全埋込型TESで求められる単純な繰り返し刺激波形で良い場合に 代表されるような状況では, 電力信号重畳伝送システムは, 期待 できるシステムであると考えられる.

\section{References}

1) T. Namima, N. Nakagawa, K. Sugano, Y. Handa and T. Ohnuma: Trans.Biomed,Eng, Vol. 43, p. 194, (2005).

2) N. Nakagawa, T. Namima, M. Yokotsuka, Y. Handa and Y. Arai: Hinyoki Geka (in Japanese), Vol. 18, no. 1, p. 17-22, (2005)

2009年10月20日受理，2010年2月10日採録 